Check for updates

The BMJ

Cite this as: BMJ 2021;373:n1342 http://dx.doi.org/10.1136/bmi.n1342 Published: 25 May 2021

\section{Covid-19: Rich countries are putting "relationships with big pharma" ahead of ending pandemic, says Oxfam}

\author{
Elisabeth Mahase
}

Some rich countries are "continuing to put their relationships with big pharma ahead of ending this pandemic," Oxfam's health policy adviser has said in response to commitments made by G2o leaders at the Global Health Summit.

Anna Marriott described the action agreed at the end of the summit, which was co-hosted by the European Commission and Italy on 21 May, as the equivalent of throwing a bucket of water on a forest fire.

World leaders at the summit reaffirmed their support for the Access to Covid-19 Tools (ACT) Accelerator, launched by the World Health Organization just over a year ago to accelerate the development of tests, treatments, and vaccines and to ensure their equitable distribution. However, a year on-and as the global death toll from the virus surpasses three million-there is still a funding gap of $\$ 18.5 \mathrm{bn}$ (£13.1bn; €15.1bn) for the accelerator. Covax, the initiative that distributes vaccines to low income countries, also has little stock.

At the summit the G2o leaders set out the Rome declaration of principles, ${ }^{1}$ including pledges to help low and middle income countries to "build expertise and develop local and regional manufacturing capacities" and to "facilitate data sharing, capacity building, licensing agreements, and voluntary technology and know-how transfers on mutually agreed terms."

They also made vaccine pledges, including the delivery of 1.3 billion doses of vaccines from BioNTech-Pfizer (one billion), Johnson \& Johnson (200 million), and Moderna (100 million) to low income countries at no profit, and to middle income countries at lower prices, by the end of 2021.

More than a billion doses have also been committed for 2022. Meanwhile, the EU has said that it aims to donate 100 million doses of vaccines to low and middle income countries in 2021 and to build up the capacity to produce vaccines in Africa, backed by $€ 1 \mathrm{bn}$ (£o.86bn; \$1.22bn) of funding. ${ }^{2}$

\section{Uncommitted doses}

Other than these promised vaccine donations, however, the summit produced little substantive change-despite WHO's estimate that bringing the pandemic to an end through the ACT-Accelerator would cost less than $1 \%$ of what governments are spending on stimulus packages to treat the consequences of the pandemic.

WHO’s director general, Tedros Adhanom Ghebreyesus, said, "We need to close the \$18.5bn funding gap...We need countries to donate tens of millions of doses of vaccines immediately through Covax...We need companies to help make donations happen fast, and to give Covax the first right of refusal on all uncommitted doses now, in 2021."

He also called for vaccine production to be "urgently and dramatically" scaled up, through "voluntary licensing, sharing technology and know-how, and waiving intellectual property rights."

Marriott, who is the policy co-lead for the People's Vaccine Alliance, said that while world leaders spoke eloquently about the "gross inequalities of global vaccinations," their solutions were still the "same tired ones that have failed billions of people who remain unvaccinated and vulnerable to infection. Nine people are dying every minute [of covid-19] while the vaccine stores of Covax-a multilateral initiative to get vaccines to developing countries-lie empty."

She added, "Governments representing the vast majority of the world's people are calling for an end to the corporate vaccine monopolies and demanding the mandatory sharing of the rights in order to produce more doses. But a handful of rich countries are continuing to put their relationships with big pharma ahead of ending this pandemic."

Marriott said that the G2o leaders had "once again ceded control of this pandemic to a handful of pharmaceutical corporations which have had more than a year to voluntarily share their intellectual property and know-how but have instead put profits before people at every turn."

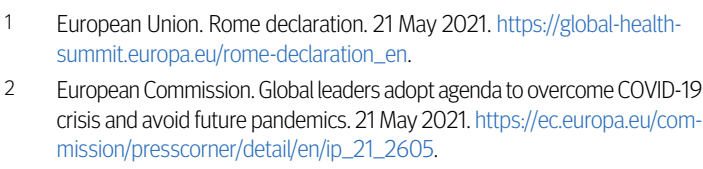

1 European Union. Rome declaration. 21 May 2021. https://global-healthsummit.europa.eu/rome-declaration_en.

2 European Commission. Global leaders adopt agenda to overcome COVID-19 crisis and avoid future pandemics. 21 May 2021. https://ec.europa.eu/commission/presscorner/detail/en/ip_21_2605.

This article is made freely available for use in accordance with BMJ's website terms and conditions for the duration of the covid-19 pandemic or until otherwise non-commercial purpose (including text and data mining) provided that all copyright notices and trade marks are retained. determined by BMJ. You may use, download and print the article for any lawful, 